\title{
A New Framework to Build a Touristic Strategy in Global Destination Management
}

\author{
Marco Benvenuto $^{1}$, Francesco V. Sambati ${ }^{1} \&$ Carmine Viola $^{1}$ \\ ${ }^{1}$ Università del Salento, Italy \\ Correspondence: Francesco V. SAMBATI, Dept. of Economical Sciences, Università del Salento, Italy. E-mail: \\ francesco.sambati@unisalento.it
}

Received: February 14, 2020

Accepted: March 11, 2020

Online Published: April 15, 2020

doi:10.5539/ijbm.v15n5p133

URL: https://doi.org/10.5539/ijbm.v15n5p133

\begin{abstract}
Globalization age led to creation of new markets and to unveil new scenarios. This contingency highlighted the existence of a broader range of tourist offerings; a factor which, frequently, has undermined the most traditionally established destinations. The model of new destinations must not ignore the peculiarities of territories on they insist creating a unique amalgam and differentiating it from other neighboring or similar destinations. Due to this proliferation of factors that destabilize the governance of tourism management models in the public and private sector, it is necessary to start an analysis of government indicators that consider peculiar aspects of destination management in the era of globalization. For these reasons we conducted an analysis of the business-economic literature about the themes of tourism and governance in tourist destinations and we selected a set of indicators to describe, assess and control extended, slow and sustainable destinations. In this work, we want to illustrate a heuristic approach to build glocal destination based on the pillars of extended, slow and sustainable tourism. From the results of the literature analysis it will be possible to create a framework to build a tourist strategy in glocal destination management, useful to implementation of territorial tourism strategies for both institutional, public and private actors. The use of the key factors of the model could favor the insertion of new tourist routes respecting the cornerstones of the tourism ecosystem of sustainability.
\end{abstract}

Keywords: corporate social responsibility, destination management, destination strategy, sustainable destination

\section{Introduction}

Creating innovation in the destination experience offers new opportunities to develop an holistic model between the destination marketing, management theory, and practice (Gardiner \& Scott, 2018). So public and private entities are playing a new proactive role in this scientific area to influence positive outcomes. Moreover the convergence of organic, incremental innovation and government development can lead to sustainable mass tourism with new models and plans. Innovation framework is often a central part of the core strategy for a regulation tourism market access. It appears difficult using such existing frameworks to model efficient turist strategy in glocal destination management because such methods require more generalisation and flexibility. In this paper we propose an innovative framework with the idea to create 'route-map indicators' for researchers and professionals. The issue of the glocal destination management is relevant to both demand and supply-side perspectives of tourist destination marketing. This paper aims to identify the trajectories of tourism development for the actors within the changing international markets; in order to identify these trajectories, from a preliminary analysis of the literature, interesting managerial research question emerged that could deliver to the theoretical development of tourism management results useful for scientific progress: can the concept of sustainability be represented by managerial indicators that allow to generate information to define new governance model? To be able to answer it, we need necessary to conduct a more structured examination of the literature. We applied an inductive methodology to identify the keywords helpful to define a framework; this instrument could be capable to highlight indicators to potential stakeholders in order to measure their ability to adapt their tourism governance models to the most current and therefore long-lasting ones.

\section{Background}

Since the 1990s, great changes have taken place in the economic and social field. They also influenced the tourism sector (Fernando \& Long, 2012; Martini, 2017), forcing it to open up to globalization and, therefore, to compete at global level (Musaro, 2013). In fact, globalization has led to the creation of new and competitive 
markets, characterized by the presence of large multinationals, with strong bargaining power. This scenario, with greater safety and economy of transport services, unveiled a much wider tourist offer; in many situations, these new conditions undermined the destinations that established their reputation over time. At the same time, the different behaviors of consumers changed their way of living, their dreams and their expectations, distorting key elements of tourist demand, such as the period and length of stay. While the digital revolution changed the approach used by tourism organizations to sell and communicate their products and services, the web has certainly become the most effective tool to acquire information, to quickly identify the alternatives and to choose the destination where to spend holidays (Di Vittorio, 2011). The tourism sector moved towards an offer system whose competitive capacity depended on the territorial resources and on the strategic and management program of systems (Martini, 2017). This approach is particularly important: infact destinations have to combine tourist services (for example: transport, and entertainment) with their own potential attractive factors (natural beauty, geographical location, heritage cultural and folklore) (Goffi, 2010). On the other hand, operators must be able to match the territorial resources with the expectations of tourists, transforming them in "a multiplier of the configurable strategic opportunities for the tourism products offered" (Della Corte, 2013).

Therefore, the tourism products became the result of a complex system with different actors, contributing to formulating a wide and differentiated offer and taking into account the characteristics of the tourist destination and the market demands (Valeri \& Fadlon, 2018). The final product, if it is well formulated and conceived, coincides with the territory and local resources: the latter are attractive factors that can capture the turistic demand.

In the tourism sector, the product is complex because it represents the result of interactions between supply and demand, the segmentation, the number and types of stakeholders and, finally, the decision-making activities (Bordas, 2012). To unify the components previously listed with the territory a systemic approach could be a useful tool to incorporate new interpretative models that support tourism production processes (Eugene, Judith, \& Michael, 2009; Wang \& Tong, 2009).

Concerning the development of local tourism contexts, that are defined as a "tourist systems", they can be used as an analysis tool both for tourism production and for management. The transition from industrial eco-systems to the globalized market led territories to acquire more value, becoming a fundamental component of what today must be conceived as a "tourism system". The territory has now passed the ancient definition of geographical area in which production is determined: it has become a container of resources, skills, and knowledge capable of enhancing natural and cultural attractions, making it competitive in the globalized market (Barucci, Becheri, \& SVIMEZ, 2006). The "destination management" theory can be a useful tool for achieving the aforementioned objective. In "destination management" the territory plays a predominant role, being defined as "the set of components of equipment (natural, artistic, structural, urban planning, infrastructural) and systemic structures (companies, organizations social, individuals, institutional bodies) confined to a defined physical space" (Golinelli, 2002). The creation of value for the most representative stakeholders it is a useful strategy for the pursuit of this goal (Cetin, Cetin, Sevik, \& Sevik, 2016); it is a process that consists in achieving a set of heterogeneous and, very often, contradictory objectives. The vocation of the territory, more commonly defined as "genius loci", is understood as "the potential for development that emerges in a given interval of time, from the natural, social, cultural and economic inclination of the territory" (Mintzberg, 1989). Over time, this can be influenced by various social factors such as the interactions between the territorial components or the presence of customs, laws, and behaviors that can determine the increase or the depletion of the social capital (Paniccia \& Leoni, 2015).

The integration between the territory, actors and their activities become strategic and characterizing. According to this approach operators can be variously composed, broad, and cohesive. They can be producers of goods, services, and information, both in the public and private sectors.

The transformations described so far have focused on the identification of a system capable of creating coherent, integrated, qualified, and organized systems. Destination management becomes "the set of strategic, organizational and operational decisions through which to manage the process of defining and promoting tourism products expressed by whole territory, and not only by the tourism sector". It is strategic "to generate incoming tourist flows and maintain the attractiveness and, therefore, competitiveness, of the tourist destinations in long term"(Martini, Baccarani, \& Franch, 2005).

The concept of destination, recently, was increasingly used to identify, at the same time, tourist attraction points in space (place) and over time (event planning). In literature, a thriving beating was developed on this topic, for which it is customary to find equivalent names of the term "destination" - as area, place, region, district, district, system - accompanied by the adjective tourist. The destination can be studied from multiple perspectives: it can 
be analyzed by the demand or the offer, or considered as a unit of analysis of a research. This last approach seems to be interesting because the classical reciprocity between demand and tourist offer is realized (Viola \& Benvenuto, 2017).

In literature, there is a vast scientific production on the themes of tourism and sustainable development. Sustainability is not uniquely defined and universally accepted since there is a triple-bottom-line that is difficult to decline today (Chang, DiGiovanni, \& Mei, 2019). Brundtland report of 1987 is the most famous document that defined the concept using foundations upon which sustainability must be based (M. E. Jarvie, 2019):

- holistic planning and strategic decisions that link economic, economic and social dynamics;

- the importance of preserving essential ecological processes;

- the need to protect biodiversity and human heritage.

- The possibility for future generations to benefit from the same development that we now have the goal of achieving a balance between opportunity and equity between different nations (M. Jarvie, 2011). Hence the pillars of sustainable development are:

- Economic sustainability: generating prosperity among the different levels of society;

- Social sustainability: guaranteeing respect for human rights and fairness of opportunities for the whole society;

- Environmental sustainability: managing is conserving resources, with particular attention to the kind of non-renewable resources that are important for their life support.

\section{Sustainable, Slow and Widespread Tourism: A Literature Analysis for the Definition of Good Tourism Governance}

The concept of sustainability has found a wide application in tourism, generating implications not only in defining new forms of tourism, but also producing definitions of new approaches to destination management and governance.

The present literature analysis aims to construct a summary report of the most cited scientific production in the last 10 years which allows us to understand the directions of tourism, to define management concepts and governance of the destinations, as well as the related measurement mechanisms.

\subsection{Sustainable Tourism, Slow and Widespread}

Tourism is a phenomenon analyzed by economic, social and environmental disciplines. It is recognized by the scientific and internationally community and it is defined as "a set of activities carried out by people during their travels and stays in places other than their residence, for a period that goes from at least two days (minimum one overnight stay) to one year, for holiday, work or other reasons"(UNWTO, 2008). Over time, tourism has become increasingly important due to the role it plays in territorial development, it is able to influence environment, and social and economic contexts of a destination (Castellani \& Sala, 2010); for these reasons the scientific community studied it and talk about sustainable tourism (Gaodi et al., 2010; Hares, Dickinson, \& Wilkes, 2010; Mihalic, 2016).

Sofield and Lia (2011), analyze the consequences of rapid Chinese economic growth starting from the high levels of organization and industrialization that have characterized the country. Their point of view focuses on the consequent depletion of natural resources and the reduction of the health status of the population. In Chinese cities the consumption of energy is over $20 \%$ compared to the average of OECD countries and China is the third country for watercourses pollution. The consequences noted by the authors can be classified substantially in the following domains: waste management, desertification and nature, and biodiversity protection. Sofield and Lia, speaking about the application of local management policies and processes for actions aimed to protect the environment, also recognized that the greatest obstacles reside in the relative implementation on the spot (Gössling, 2015; Miller, Merrilees, \& Coghlan, 2015; Radwan, Jones, \& Minoli, 2010).

Haukeland, Grue, and Veisten (2010) examined sustainable tourism from the demand side and identified different types of tourists through analysis of the literature according to their sensitivity to the environmental impacts generated by tourism. In their work they classified tourist in two macro-categories: soft and hard ecotourists. The former is characterized by soft activities and the search for comfort. The latter included all those tourists looking for completely naturalistic outdoor activities, characterized by intense physical activity and high involvement, are included (Neuhofer, Buhalis, \& Ladkin, 2012).

The concept of sustainable tourism has recently been linked to "slow tourism", characterized by a new concept 
of vacation that let tourists live completely the journey and the destination. These two elements are declined according to a new concept of slowness (Lumsdon \& McGrath, 2011) which allows tourists to abandon the rhythms typical of their routines and to fully immerse themselves in tourist destination ones (Dickinson, Robbins, \& Lumsdon, 2010; Phillips \& Moutinho, 2014). "Localness" is connected to slow tourism, understood as typical food production consumed by tourists. The food product becomes an integral part of the tourist experience and allows travelers to fully integrate with the destination (Sims, 2010).

\subsection{Destination Management}

Destination management has become recently an important issue in terms of sustainability. The strategy to realize forms of sustainable tourism must necessarily take into account continuous processes of consultation and planning with local actors. According to Castellani and Sala (2010) it is necessary to create management models that can guarantee benefits and good quality of life for residents while protecting the environment. The process must necessarily be inspired by the logic of planning-programming-control, typical of the Deming cycle, with particular attention to a continuous improvement of quality. The concept applied to destinations need to focus on five main phases. The first is to understand economic, social, cultural and environmental variables, in order to highlight the strengths and weaknesses of the territories; the second one need a consultation with local stakeholders, to verify the existence of the strengths and weaknesses of the territories; the third is focused on planning of participatory processes; the fourth is dedicated to defining a strategy aimed at the development of sustainable tourism, characterized by an action plan intimately connected with the previous phases; and the last one request a general evaluation of the strategy and planned improvement actions.

Logar (2010) identified different policy tools that can support the application of sustainable management of a destination, all the tools introduced by the author are aimed to mitigate the demand for tourist services, or aimed to attract tourist segments that are particularly concerned with their impact on the community and the environment.

Tourism sustainability was also analyzed by the accessibility of the destination concerning the most common disability. Darcy, Cameron, and Pegg (2010) affirm that the best strategy that a tour operator could use to better align with needs of this customer segment is to introduce some of the following elements: the absence of architectural barriers; adaptation to international accessibility standards; involve subjects with disabilities in the planning rather than specialists. Finally, according to Lee, Huang, and Yeh (2010), different elements contribute to the sustainability of a destination, including tourist attractions, accessibility, amenities, and complimentary services.

\subsection{Tourist Governance}

Imran, Alam, and Beaumont (2014) focused their study on the effectiveness of local tourism governance concerning the objectives that the institutions had to achieve about their stakeholders. The authors highlight how institutional structures can be formal and informal networks characterized by an organizational autonomy, by its authority, with an internal coherence and governed by a set of rules. Tourist governance generally assume a form of public-private partnership that characterizes the decisions taken into specific issues through financial support, transfer of knowledge, and co-construction of skills for tourism industry. Scientific evidence shows that these structures are not static, settling and isolated about the context in which they operate, but they seem characterized by a slow change that allows them to transfer a set of values and practices, through a set of relationships that enhance the governance structure (Lane \& Kastenholz, 2015; Sakata \& Prideaux, 2013). The theme of networks in sustainable destination governance was analyzed by Erkuş-Öztürk and Eraydin (2010), they observe that most of the problems in tourism planning originate from different actors involved and from different conceptions they have about sustainability. There is a widespread literature stating that tourist governance is also affected by different levels of power expressed by the partners (Beritelli, 2011; Dredge \& Whitford, 2011; Hall, 2010; Saufi, O’Brien, \& Wilkins, 2014; Sofield \& Lia, 2011; Stylidis, Biran, Sit, \& Szivas, 2014).

\section{Sustainability Indicators for the Tourist Destinations}

Literature analysis expressed interesting insights and proposals about the nature and the structure of indicators used to describe the tourist destination from a sustainability perspective. As different authors stated, sustainable tourism (Table 1) is a concept that includes three different and balanced dimensions: social, economic and environmental.

The 30 indicators identified through literature analysis can be grouped into three macro-categories: demographic characteristics (such as population structure, age and expectation of life); population-based services (concerning, 
for example, the conservation of culture or related to recreational services); impact of tourism on the population. The social dimension is flanked by the economic one, it includes 40 indicators clustered in: tourist (relating to the demand and the tourist offer); economic (able to highlight the impact of tourism on the community) and infrastructures (such as indicators related to infrastructure / roads, or to the development of telematics). The last dimension dedicated to sustainability is the environmental dimension: the 30 indicators are focused on the impact of tourism on environment. These include, for example, all the indices linked to the management of protected areas, waste management and consumption of water resources.

Table 1. Sustainable tourism indicators

\begin{tabular}{|c|c|c|}
\hline \multirow{50}{*}{ Sustainable tourism } & \multicolumn{2}{|l|}{ Social dimension } \\
\hline & \multicolumn{2}{|l|}{ Sport facilities per inhabitant } \\
\hline & \multicolumn{2}{|l|}{ Health care equipment } \\
\hline & \multicolumn{2}{|l|}{ Number of passenger transport vehicles per inhabitant } \\
\hline & \multicolumn{2}{|l|}{ Number of financial establishments per inhabitant } \\
\hline & \multicolumn{2}{|l|}{ Number of services sector establishments per inhabitant } \\
\hline & \multicolumn{2}{|l|}{ Number of pharmacies per inhabitant } \\
\hline & \multicolumn{2}{|l|}{ Provision of toilets and showers on the beaches } \\
\hline & \multicolumn{2}{|l|}{ Evaluation of destination safety by tourists } \\
\hline & \multicolumn{2}{|l|}{ Provision of safety and emergency services on the beaches } \\
\hline & \multicolumn{2}{|l|}{ Conservation of the cultural heritage } \\
\hline & \multicolumn{2}{|l|}{ Number of cultural sites designated as "assets of cultural interest" } \\
\hline & \multicolumn{2}{|l|}{ Number of cultural volunteers } \\
\hline & \multicolumn{2}{|l|}{ Pressure on cultural heritage } \\
\hline & \multicolumn{2}{|l|}{ Variation of the population levels } \\
\hline & Percentage of young population & \multirow{6}{*}{$\begin{array}{l}\text { (Boley, } \\
\text { McGehee, } \\
\text { Perdue, \& Long, } \\
\text { 2014; Castellani } \\
\text { \& Sala, 2010; } \\
\text { Cucculelli \& }\end{array}$} \\
\hline & Percentage of non-active older population & \\
\hline & Number of individuals per unit destination area & \\
\hline & Net migration rate & \\
\hline & Rate of natural increase & \\
\hline & Percentage of foreign population & \\
\hline & Ratio of tourist to locals & Goffi, $\quad 2016$; \\
\hline & Life expectancy & Jamal \\
\hline & Variation of available income & Camargo, 2014; \\
\hline & Percentage of enrolled population in noncompulsory education & Rendeiro \\
\hline & General demographic dependency index & Martín-Cejas \& \\
\hline & Property value of real estate per inhabitant & Pablo Ramírez \\
\hline & Availability of recreational facilities & Sánchez, 2010; \\
\hline & Cultural activities/entertainment & Stylidis et al., \\
\hline & Opportunity to meet people from other cultures & 2014; Tanguay, \\
\hline & Economic dimension & Rajaonson, \& \\
\hline & Total number of tourist arrivals & Therrien, 2013; \\
\hline & Average stay & Torres-Delgado \\
\hline & Tourist spending Property value of real estate & \& Palomeque, \\
\hline & Proportion of employees in the services sector & 2014) \\
\hline & Unemployment rate & \\
\hline & Volume of registered service sector investment & \\
\hline & Number of telephone lines in service & \\
\hline & Number of ADSL lines in service per 1000 inhabitant & \\
\hline & Declared net income per inhabitant & \\
\hline & Vacancies offered in restaurants & \\
\hline & Number of tourist information offices per tourist & \\
\hline & Existence of a website that provides information about the destination & \\
\hline & Percentage of official tourism accommodation establishments which are open all year & \\
\hline & Ratio of low-season tourists to peakseason tourists & \\
\hline & Ratio of low-season tourism employment to peak-season tourism employment & \\
\hline & Total number employed in the tourism sector & \\
\hline & Percentage of employees in tourism sector relative to total employment & \\
\hline & Number of passenger transport vehicles per inhabitant & \\
\hline & Access time from the closest airport & \\
\hline
\end{tabular}




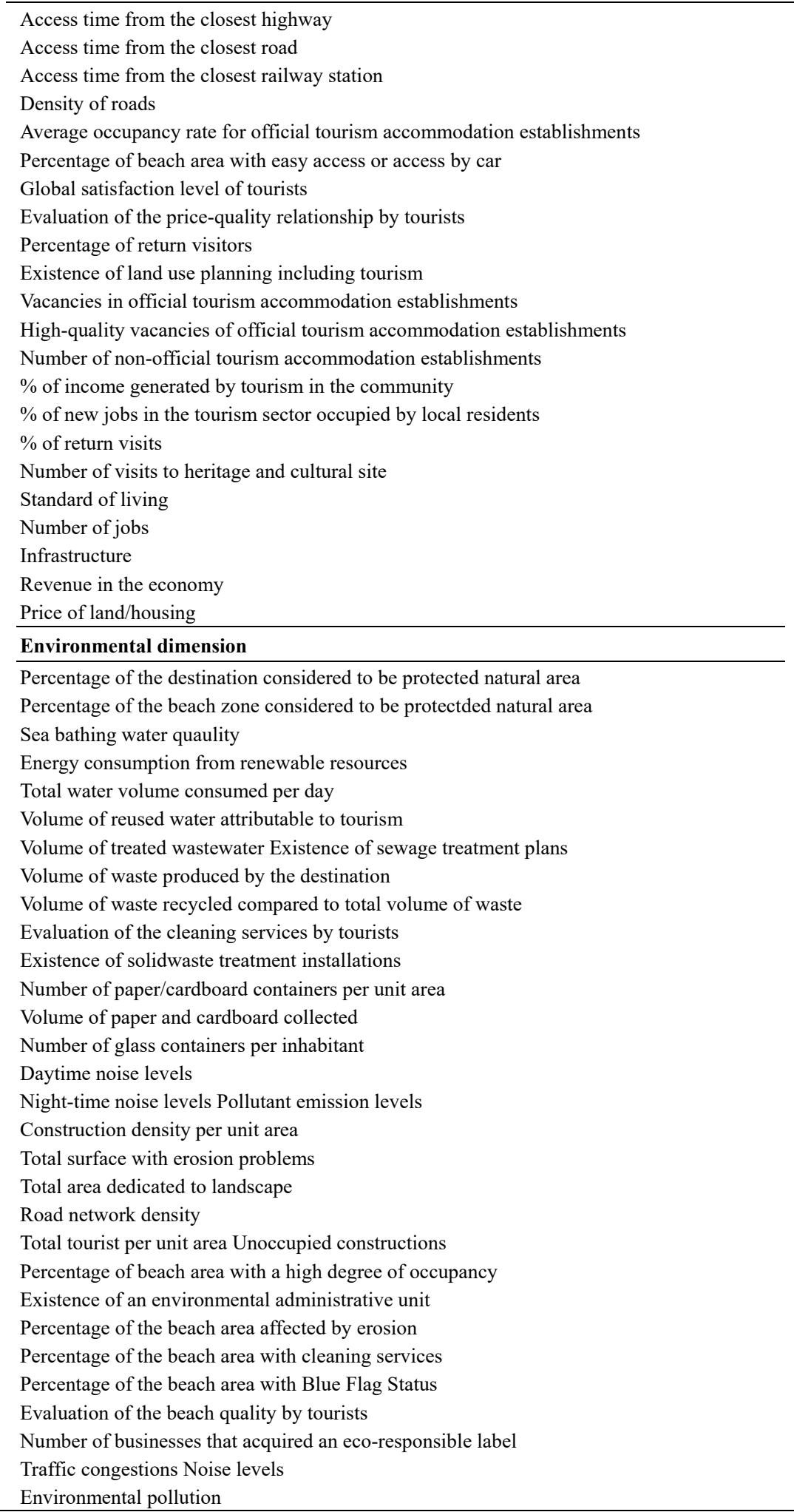

Slow and widespread tourism (Table 2), according to the definitions identified, can be described by a set of indicators that allow to focus on his typical characteristics. The 18 selected indicators consider elements that allow the tourist to be able to fully enjoy a unique experience. For example, they focus on information availability or on the chance to be able to enjoy the destination in an immersive and unique way. 
Table 2. Slow and widespread tourism indicators

More nature paths for "self- guiding"

More accessible information

More and improved rambling tracks

More picnic areas

More cycling tracks

More service persons

Increased opportunities for various activities

Zoning of different activities

(Hares et al.,

More service persons

2010; Haukeland

Staged experiences for a greater audience

et al., 2010; Sims,

Accommodation with good standard

Well developed food and beverage facilities

Abundance of accommodation

Local food specialities

Guided tour/sightseeing to see animals/natural attractions see animals/natural attractions

Guided tour/sightseeing to cultural attractions

Visitor centres with exhibitions

Supply of roads, parking areas, etc.

The management of tourist destinations (Table 3) refers to the capacity of a destination to provide services and facilities that support tourists to fully enjoy all the comfort it can provide. For this reason, 48 indicators have been identified to provide a precise description of the ability of the destination to maintain, manage and improve the elements of attraction.

Table 3. Destination Management indicators

\footnotetext{
Accessibility

Environmental value of the territory

Level of tourism and service infrastructures

Promotional policies

Level of tourism and service infrastructures

Promotional policies

Environmental Policies

Natural resources

Investment and innovation

Activation of networks

Involvement of private

Quality of the entertainment

Quality of the information provided

Institutional connection

Communication intensity

Contact ease

Information exchange

Starting initiatives

Success of initiatives

Natural resources

Climatic phenomena

Forest landscapes and scenery

Rare flora and fauna

Cultural assets

Special events

Historical structures

External access

Road network
}

(Beritelli, 2011;

Castellani \&

Sala, 2010;

Coghlan, 2012;

Hof \& Schmitt,

2011; Lee et al.,

2010) 


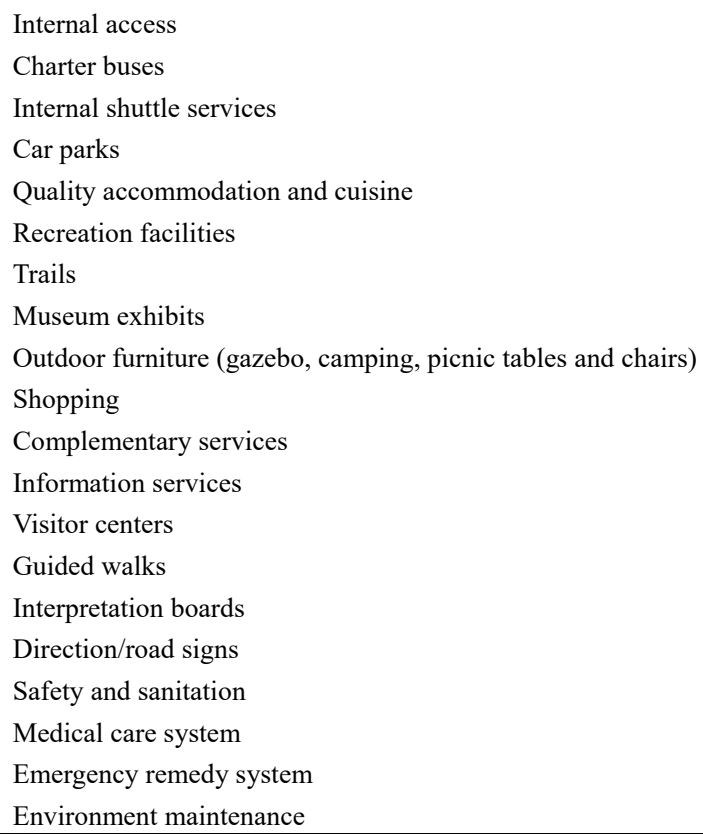

Good tourist governance must be based on the maximum capacity to generate consensus on a shared vision with the community (Table 4). For these reasons, and with the aim to maximize sustainability for the tourist communities, it becomes necessary to identify a list of indicators that can assess the impact of governance policies and initiatives that have on the social, economic, and environmental context.

Table 4. Tourist Governance indicators

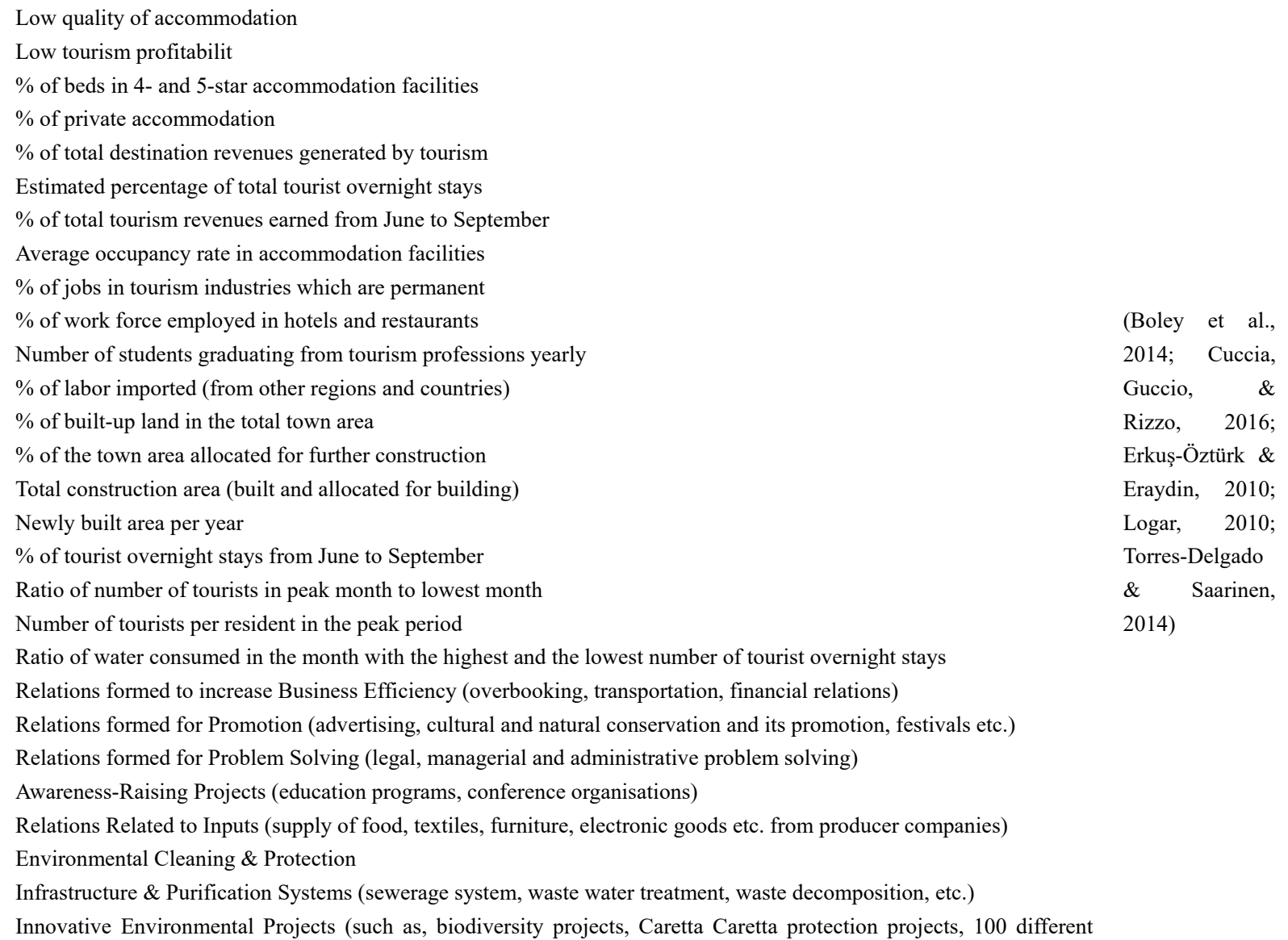


birds projects, endemic plants projects, Religious Garden Project, projects against mosquitoes, houseflies and sand flies etc.)

Awareness-raising Studies (seminars on environmental protection, education programmes, sponsorship, advertising the natural environment etc.)

Relations related to Quality Control (environmental quality and hygiene standards)

Forestation

Tourists/ha

$\%$ urban land

$\%$ land zoned for development

$\%$ non-developable land

\section{Model Definition and Discussion}

In a changed tourist context, characterized by a new sensibility towards the concept of sustainability, the slow and widespread approach to tourism can represent the suitable field to experiment a new model to evaluate and manage tourist destinations. The Tourist Ecosystem Model (Figure 1) is designed for tourist destinations that intend to apply slow and widespread forms of tourism. In these destinations, strategic planning focuses on six key elements: territory, aggregation, inclusion, internationalization, innovation and sustainability.

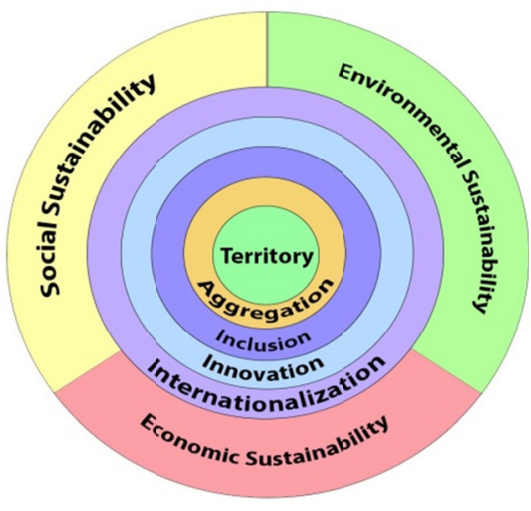

Figure 1. Tourist ecosystem model

The territory is the key element of any tourist destination, it represents the heritage to be exploited, it integrates the rural, seaside and urban areas with territorial intelligence dynamics; territorial coalitions are the foundation for building an eco-sustainable territorial system; to make a destination truly inclusive and representative, it is necessary to develop a model focused on community and fair economy; internationalization concerns the ability of the destination to maintain its distinctive and specific characteristics (tradition and culture), approaching dynamics of openness to global dynamics; innovation in destination is imagined as the creation of a social capital based on research, professionalism and competences which insist on the territory; in the end sustainability is intended as a strategic element to reaffirm the quality of life of both the community and the tourists of the destination.

Using the indicators identified by the literature analysis in the previous section, we classified and cataloged them to outline a strategic tool for analysis and control of a tourist destination characterized by a Tourist Ecosystem Model (table 5). 
Table 5. Tourist ecosystem model indicators

\begin{tabular}{|c|c|c|}
\hline Territory & Aggregation & Inclusion \\
\hline $\begin{array}{l}\text { Number of passenger transport vehicles per } \\
\text { inhabitant } \\
\text { Number of financial establishments per } \\
\text { inhabitant } \\
\text { Number of services sector establishments per } \\
\text { inhabitant } \\
\text { Conservation of the cultural heritage } \\
\text { Number of cultural sites designated as "assets of } \\
\text { cultural interest" } \\
\text { Pressure on cultural heritage } \\
\text { Number of tourist information offices per tourist } \\
\text { Access time from the closest airport } \\
\text { Newly built area per year } \\
\text { Density of roads } \\
\text { Vacancies in official tourism accommodation } \\
\text { establishments } \\
\text { Number of non-official tourism accommodation } \\
\text { establishments } \\
\text { Number of visits to heritage and cultural site } \\
\text { Existence of solidwaste treatment installations } \\
\text { Construction density per unit area } \\
\text { Total surface with erosion problems } \\
\text { Total area dedicated to landscape } \\
\text { Road network density } \\
\text { Guided tour/sightseeing to see animals/natural } \\
\text { attractions see animals/natural attractions } \\
\text { Guided tour/sightseeing to cultural attractions }\end{array}$ & $\begin{array}{l}\text { Property value of real estate per } \\
\text { inhabitant } \\
\text { Availability of recreational facilities } \\
\text { Sport facilities per inhabitant } \\
\text { Cultural activities/entertainment } \\
\text { Accessible information } \\
\text { Number of picnic areas } \\
\text { Number of cycling tracks } \\
\text { Number of service persons } \\
\text { Increased opportunities for various } \\
\text { activities } \\
\text { Zoning of different activities } \\
\text { Recreation facilities } \\
\text { Activation of networks } \\
\text { Relations related to inputs (supply of } \\
\text { food, textiles, furniture, electronic goods } \\
\text { etc. from producer companies) }\end{array}$ & $\begin{array}{l}\text { Net migration rate } \\
\text { Percentage of foreign population } \\
\text { Opportunity to meet people from other } \\
\text { cultures } \\
\text { Percentage of non-active older population } \\
\text { Percentage of enrolled population in } \\
\text { noncompulsory education } \\
\text { Unemployment rate } \\
\% \text { of income generated by tourism in the } \\
\text { community } \\
\text { \% of new jobs in the tourism sector } \\
\text { occupied by local residents } \\
\text { Percentage of employees in tourism sector } \\
\text { relative to total employment } \\
\text { Proportion of employees in the services } \\
\text { sector } \\
\text { Involvement of private } \\
\text { Information services } \\
\text { Visitor centers } \\
\text { Guided walks }\end{array}$ \\
\hline
\end{tabular}

Guided tour/sightseeing to cultural attractions

\begin{tabular}{|c|c|}
\hline Internationalization & Innovation \\
\hline Ratio of tourist to locals & Number of cultural volunteers \\
\hline Total number of tourist arrivals & Number of ADSL lines in service per mil inhabitant \\
\hline Average stay & Number of telephone lines in service \\
\hline Tourist spending & Existence of a website that provides information about the \\
\hline Ratio of low-season tourists to peakseason tourists & destination \\
\hline Ratio of low-season tourism employment to peak-season tourism & Number of businesses that acquired an eco-responsible label \\
\hline employment Total number employed in the tourism sector & Existence of an environmental administrative unit \\
\hline Percentage of official tourism accommodation establishments which & Well developed food and beverage facilities \\
\hline are open all year & Accessibility \\
\hline Information exchange & Promotional policies \\
\hline Institutional connection & Environmental Policies \\
\hline Communication intensity & Promotional policies \\
\hline \multirow[t]{4}{*}{ Quality of the information provided } & $\begin{array}{l}\text { Awareness-Raising Projects (education programs, conference } \\
\text { organisations) }\end{array}$ \\
\hline & Infrastructure \& Purification Systems \\
\hline & Innovative Environmental Projects \\
\hline & $\begin{array}{l}\text { Awareness-raising Studies (seminars on environmental protection, } \\
\text { education programmes, sponsorship, advertising the natural } \\
\text { environment etc.) }\end{array}$ \\
\hline
\end{tabular}

Sustainability

\begin{tabular}{lll}
\hline \multicolumn{1}{c}{ Social } & \multicolumn{1}{c}{ Economic } & \multicolumn{1}{c}{ Environmental } \\
\hline Health care equipment & Variation of available income & Number of individuals per unit destination \\
Number of pharmacies per inhabitant & Average occupancy rate for official & area \\
Variation of the population levels & tourism accommodation establishments & Rate of natural increase \\
Percentage of young population & Price of land/housing & Percentage of the destination considered to
\end{tabular}




\begin{tabular}{|c|c|c|}
\hline $\begin{array}{l}\text { Life expectancy } \\
\text { Medical care system } \\
\text { Local food specialities } \\
\% \text { of labor imported (from other regions and } \\
\text { countries) }\end{array}$ & $\begin{array}{l}\text { Property value of real estate } \\
\text { Declared net income per inhabitant } \\
\text { Percentage of beds in } 4 \text { - and 5-star } \\
\text { accommodation facilities } \\
\text { Percentage of private accommodation } \\
\text { Percentage of total destination revenues } \\
\text { generated by tourism } \\
\text { Percentage of total tourism revenues } \\
\text { earned from June to September } \\
\text { Percentage of jobs in tourism industries } \\
\text { which are permanent } \\
\text { Percentage of work force employed in } \\
\text { hotels and restaurants }\end{array}$ & $\begin{array}{l}\text { be protected natural area } \\
\text { Percentage of the beach zone considered to } \\
\text { be protectded natural area } \\
\text { Sea bathing water quality } \\
\text { Energy consumption from renewable } \\
\text { resources } \\
\text { Total water volume consumed per day } \\
\text { Volume of reused water attributable to } \\
\text { tourism } \\
\text { Volume of treated wastewater Existence of } \\
\text { sewage treatment plans } \\
\text { Volume of waste produced by the } \\
\text { destination } \\
\text { Volume of waste recycled compared to total } \\
\text { volume of waste } \\
\text { Environmental pollution } \\
\text { Ratio of water consumed in the month with } \\
\text { the highest and the lowest number of tourist } \\
\text { overnight stays }\end{array}$ \\
\hline
\end{tabular}

\section{Conclusions}

Nowadays a tourist destination must no longer be just an attractor, registering high number of arrivals and stays. It is no longer sufficient to provide the basic tourist services to have a destination pleasant, but it is necessary to develop a joint action that sees actors, communities and tourists work together to preserve local assets (Dodds, Graci, \& Holmes, 2010). Natural, cultural, historical or landscape amenities (Beritelli, 2011) represent a unicum that allows a territory to compete on a local and global scale (Martini, 2017), those element are the basis of ecotourism (Haukeland et al., 2010). While destinations hold or can create facilitators that allow tourists to reach them physically or virtually (Lee et al., 2010), on the other side they need a careful programming, planning, and control activities (Logar, 2010) that allow them to preserve uniqueness of their assets for as long as possible.

To compete in the tourism sector, a destination has to maintain its competitive advantage over rival destinations that, thanks to the web and transport systems (ever faster, safer and cheaper), are more easily identifiable and reachable by tourists (Viola \& Benvenuto, 2017). To date the competition is taken to a new level: the uniqueness of the destination. In order to result unique, a destination need to understand the territories, to analyze the tourism impacts according to the triple bottom line of sustainability (Gaodi et al., 2010; Hares et al., 2010; Mihalic, 2016), and to define the dynamics that lead to good management and governance (Imran et al., 2014). But destination management need to consider other aspects deeply connected with tangible and intangible resources of a territory (Castellani \& Sala, 2010). Social impacts are strategic to gather the relationships that are triggered between tourism and community (Boley et al., 2014; Jamal \& Camargo, 2014; Stylidis et al., 2014); the economic ones measure the weight of tourism on the local economy (Torres-Delgado \& Saarinen, 2014); environmental impacts assess the pressure generated on environment, natural resources and landscape (Cucculelli \& Goffi, 2016; Rendeiro Martín-Cejas \& Pablo Ramírez Sánchez, 2010). These impacts, however, are not yet sufficient. When a tourist territory evolves into a destination, it needs tools that allow it to tangibly measure the consequences of the strategies implemented and the degree of involvement and participation of the local actors.

For these reasons, the indicators selected from the literature analysis and reclassified in table 5 can represent a starting point for analyzing and monitoring a tourist destination characterized by a slow and widespread tourism (Haukeland et al., 2010), comparing it with similar destinations and / or nearby ones, according to the Tourist Ecosystem Model (Figure 1): territory, aggregation, inclusion, internationalization, innovation and sustainability.

In order to be implemented, the results thus far adduced need to be applied to heterogeneous cases and it would deserve an application in the medium to long term. In addition, the business, social, and environmental context of the territories presents different aggregates, both in size and in structural terms, therefore it would be necessary to normalize the model and apply it in order to obtain results in line with the characteristics of genius loci (Mintzberg, 1989). 


\section{Acknowledgments}

This article was created on the basis of the objectives and purposes of the FAME Road project (Food Art Movement Energy - the ROAD to Country Experience), financed with the Interreg V- A Greece-Italy Program 2014-2020 measure.

\section{References}

Barucci, P., Becheri, E., \& Svimez. (2006). L'industria turistica nel mezzogiorno: rapporto. Bologna: Il Mulino.

Beritelli, P. (2011). Cooperation among prominent actors in a tourist destination. Annals of Tourism Research, 38(2), 607-629. https://doi.org/10.1016/j.annals.2010.11.015

Boley, B. B., McGehee, N. G., Perdue, R. R., \& Long, P. (2014). Empowerment and resident attitudes toward tourism: Strengthening the theoretical foundation through a Weberian lens. Annals of Tourism Research, 49, 33-50. https://doi.org/10.1016/j.annals.2014.08.005

Bordas, E. (2012). Competitiveness of Tourist Destinations in Long Distance Markets. Competitiveness and Tourism, 1, 170-176.

Castellani, V., \& Sala, S. (2010). Sustainable performance index for tourism policy development. Tourism Management, 31(6), 871-880. https://doi.org/10.1016/j.tourman.2009.10.001

Cetin, M., Cetin, M., Sevik, H., \& Sevik, H. (2016). Evaluating the recreation potential of Ilgaz Mountain National Park in Turkey. Environmental Monitoring and Assessment, 188, 1-10. https://doi.org/10.1007/s10661-015-5064-7

Chang, C. C., DiGiovanni, K., \& Mei, Y. (2019). Sustainability. Water Environment Research, 91, 1129-1149. https://doi.org/10.1002/wer.1210

Coghlan, A. (2012). Facilitating reef tourism management through an innovative importance-performance analysis method. Tourism Management, 33(4), 767-775. https://doi.org/10.1016/j.tourman.2011.08.010

Cuccia, T., Guccio, C., \& Rizzo, I. (2016). The effects of UNESCO World Heritage List inscription on tourism destinations performance in Italian regions. Economic Modelling, 53, 494-508. https://doi.org/10.1016/j.econmod.2015.10.049

Cucculelli, M., \& Goffi, G. (2016). Does sustainability enhance tourism destination competitiveness? Evidence from Italian Destinations of Excellence. Journal of Cleaner Production, 111, 370-382. https://doi.org/10.1016/j.jclepro.2014.12.069

Darcy, S., Cameron, B., \& Pegg, S. (2010). Accessible tourism and sustainability: A discussion and case study. Journal of Sustainable Tourism, 18(4), 515-537. https://doi.org/10.1080/09669581003690668

Della Corte, V. (2013). Imprese e sistemi turistici: il management. Milano: EGEA.

Di Vittorio, A. (2011). Turismo 2.0: le community on line dei viaggiatori e la condivisione dell'esperienza turistica. Mercati E Competitività, 147-167.

Dickinson, J. E., Robbins, D., \& Lumsdon, L. (2010). Holiday travel discourses and climate change. Journal of Transport Geography, 18(3), 482-489. https://doi.org/10.1016/j.jtrangeo.2010.01.006

Dodds, R., Graci, S. R., \& Holmes, M. (2010). Does the tourist care? A comparison of tourists in Koh Phi Phi, Thailand and Gili Trawangan, Indonesia. Journal of Sustainable Tourism, 18(2), 207-222. https://doi.org/10.1080/09669580903215162

Dredge, D., \& Whitford, M. (2011). Event tourism governance and the public sphere. Journal of Sustainable Tourism, 19(4-5), 479-499. https://doi.org/10.1080/09669582.2011.573074

Erkuş-Öztürk, H., \& Eraydin, A. (2010). Environmental governance for sustainable tourism development: Collaborative networks and organisation building in the Antalya tourism region. Tourism Management, 31(1), 113-124. https://doi.org/10.1016/j.tourman.2009.01.002

Eugene J., A. E. I., E., Judith, E., O., \& Michael, A., U. (2009). Tinapa Business Resort: A Strategy for Sustainable Rural Livelihood in Cross River State, Nigeria. International Journal of Business and Management, 4(6). https://doi.org/10.5539/ijbm.v4n6p121

Fernando, I. N., \& Long, W. (2012). New Conceptual Model on Cluster Competitiveness: A New Paradigm for Tourism? International Journal of Business and Management, 7(9). https://doi.org/10.5539/ijbm.v7n9p75

Gaodi, X., Wenhua, L., Yu, X., Biao, Z., Chunxia, L., Kai, A., ... Jinzeng, W. (2010). Forest ecosystem services 
and their values in Beijing. Chinese Geographical Science, 20(1), 051-058. https://doi.org/10.1007/s11769-010-0051-y

Gardiner, S., \& Scott, N. (2018). Destination Innovation Matrix: A framework for new tourism experience and market development. Journal of Destination Marketing \& Management, 10, 122-131. https://doi.org/10.1016/j.jdmm.2018.07.002

Goffi, G. (2010). Management delle destinazioni turistiche: sfide per territori e imprese : il caso di Senigallia e delle Valli Misa e Nevola. Milano: FrancoAngeli.

Golinelli, C. M. (2002). Il territorio sistema vitale. Verso un modello di analisi. In Giappichelli (Ed.), Economia della Cultura. https://doi.org/10.1446/12396

Gössling, S. (2015). New performance indicators for water management in tourism. Tourism Management, 46, 233-244. https://doi.org/10.1016/j.tourman.2014.06.018

Hall, C. M. (2010). Changing paradigms and global change: From sustainable to steady-state tourism. Tourism Recreation Research, 35(2), 131-143. https://doi.org/10.1080/02508281.2010.11081629

Hares, A., Dickinson, J., \& Wilkes, K. (2010). Climate change and the air travel decisions of UK tourists. Journal of Transport Geography, 18(3), 466-473. https://doi.org/10.1016/j.jtrangeo.2009.06.018

Haukeland, J. V., Grue, B., \& Veisten, K. (2010). Turning national parks into tourist attractions: Nature orientation and quest for facilities. Scandinavian Journal of Hospitality and Tourism, 10(3), 248-271. https://doi.org/10.1080/15022250.2010.502367

Hof, A., \& Schmitt, T. (2011). Urban and tourist land use patterns and water consumption: Evidence from Mallorca, Balearic Islands. Land Use Policy, 28(4), $792-804$. https://doi.org/10.1016/j.landusepol.2011.01.007

Imran, S., Alam, K., \& Beaumont, N. (2014). Environmental orientations and environmental behaviour: Perceptions of protected area tourism stakeholders. Tourism Management, 40, 290-299. https://doi.org/10.1016/j.tourman.2013.07.003

Jamal, T., \& Camargo, B. A. (2014). Sustainable tourism, justice and an ethic of care: toward the Just Destination Journal of Sustainable Tourism, 22(1), 11-30. https://doi.org/10.1080/09669582.2013.786084

Jarvie, M. (2011). Brundtland Report. Green Ethics and Philosophy: An A-to-Z Guide, pp. 41-43.

Jarvie, M. E. (2019). Brundtland Report. Encyclopædia Britannica Inc.

Lane, B., \& Kastenholz, E. (2015). Rural tourism: the evolution of practice and research approaches - towards a new generation concept? Journal of Sustainable Tourism, 23(8-9), 1133-1156. https://doi.org/10.1080/09669582.2015.1083997

Lee, C. F., Huang, H. I., \& Yeh, H. R. (2010). Developing an evaluation model for destination attractiveness: Sustainable forest recreation tourism in Taiwan. Journal of Sustainable Tourism, 18(6), 811-828. https://doi.org/10.1080/09669581003690478

Logar, I. (2010). Sustainable tourism management in Crikvenica, Croatia: An assessment of policy instruments. Tourism Management, 31(1), 125-135. https://doi.org/10.1016/j.tourman.2009.02.005

Lumsdon, L. M., \& McGrath, P. (2011). Developing a conceptual framework for slow travel: A grounded theory approach. Journal of Sustainable Tourism, 19(3), 265-279. https://doi.org/10.1080/09669582.2010.519438

Martini, U. (2017). Management e marketing delle destinazioni turistiche e territoriali: metodi, approcci e strumenti. Milano: McGraw Hill education.

Martini, U., Baccarani, C., \& Franch, M. (2005). Management dei sistemi territoriali: gestione di marketing delle destinazioni turistiche (Vol. 10). Vol. 10. Torino: Giappichelli.

Mihalic, T. (2016). Sustainable-responsible tourism discourse - Towards "responsustable" tourism. Journal of Cleaner Production, 111, 461-470. https://doi.org/10.1016/j.jclepro.2014.12.062

Miller, D., Merrilees, B., \& Coghlan, A. (2015). Sustainable urban tourism: understanding and developing visitor pro-environmental behaviours. Journal of Sustainable Tourism, 23(1), 26-46. https://doi.org/10.1080/09669582.2014.912219

Mintzberg, H. (1989). The Structuring of Organizations. In Readings in Strategic Management (pp. 322-352). https://doi.org/10.1007/978-1-349-20317-8_23 
Musaro, P. (2013). Come coniugare crescita e benessere? Il turismo responsabile in prospettiva glocale. (How to Combine Growth and Well-Being? Responsible Tourism from a Glocal Point of View. With English summary). Sociologia Del Lavoro, 143-157.

Neuhofer, B., Buhalis, D., \& Ladkin, A. (2012). Conceptualising technology enhanced destination experiences. Journal of Destination Marketing and Management, 1(1-2), 36-46. https://doi.org/10.1016/j.jdmm.2012.08.001

Paniccia, P., \& Leoni, L. (2015). Alberghi diffusi in contesti storici: Dalle suggestioni dell'innovazione alla reale esigenza della sostenibilità. https://doi.org/10.7433/SRECP.2015.32

Phillips, P., \& Moutinho, L. (2014). Critical review of strategic planning research in hospitality and tourism. Annals of Tourism Research, 48, 96-120. https://doi.org/10.1016/j.annals.2014.05.013

Radwan, H. R. I., Jones, E., \& Minoli, D. (2010). Managing solid waste in small hotels. Journal of Sustainable Tourism, 18(2), 175-190. https://doi.org/10.1080/09669580903373946

Rendeiro Martín-Cejas, R., \& Pablo Ramírez Sánchez, P. (2010). Ecological footprint analysis of road transport related to tourism activity: The case for Lanzarote Island. Tourism Management, 31(1), 98-103. https://doi.org/10.1016/j.tourman.2009.01.007

Sakata, H., \& Prideaux, B. (2013). An alternative approach to community-based ecotourism: A bottom-up locally initiated non-monetised project in Papua New Guinea. Journal of Sustainable Tourism, 21(6), 880-899. https://doi.org/10.1080/09669582.2012.756493

Saufi, A., O'Brien, D., \& Wilkins, H. (2014). Inhibitors to host community participation in sustainable tourism development in developing countries. Journal of Sustainable Tourism, 22(5), 801-820. https://doi.org/10.1080/09669582.2013.861468

Sims, R. (2010). Putting place on the menu: The negotiation of locality in UK food tourism, from production to consumption. Journal of Rural Studies, 26(2), 105-115. https://doi.org/10.1016/j.jrurstud.2009.09.003

Sofield, T., \& Lia, S. (2011). Tourism governance and sustainable national development in China: A macro-level synthesis. Journal of Sustainable Tourism, https://doi.org/10.1080/09669582.2011.571693

Stylidis, D., Biran, A., Sit, J., \& Szivas, E. M. (2014). Residents' support for tourism development: The role of residents' place image and perceived tourism impacts. Tourism Management, 45, $260-274$. https://doi.org/10.1016/j.tourman.2014.05.006

Tanguay, G. A., Rajaonson, J., \& Therrien, M. C. (2013). Sustainable tourism indicators: Selection criteria for policy implementation and scientific recognition. Journal of Sustainable Tourism, 21(6), 862-879. https://doi.org/10.1080/09669582.2012.742531

Torres-Delgado, A., \& Palomeque, F. L. (2014). Measuring sustainable tourism at the municipal level. Annals of Tourism Research, 49, 122-137. https://doi.org/10.1016/j.annals.2014.09.003

Torres-Delgado, A., \& Saarinen, J. (2014). Using indicators to assess sustainable tourism development: a review. Tourism Geographies, 16(1), 31-47. https://doi.org/10.1080/14616688.2013.867530

UNWTO. (2008). Understanding Tourism: Basic Glossary. Springer International Publishing, 2008, 1-4.

Valeri, M., \& Fadlon, L. (2018). Co-Evolutionary Prospects in Tourism. International Journal of Business and Management, 13(9), 95. https://doi.org/10.5539/ijbm.v13n9p95

Viola, C., \& Benvenuto, M. (2017). Profili economico - aziendali per il governo delle aziende turistiche locali / Carmine Viola, Marco Benvenuto. Roma: Rirea.

Wang, H., \& Tong, M. (2009). Research on Community Participation in Environmental Management of Ecotourism. International Journal of Business and Management, 4(3). https://doi.org/10.5539/ijbm.v4n3p131

\section{Copyrights}

Copyright for this article is retained by the author(s), with first publication rights granted to the journal.

This is an open-access article distributed under the terms and conditions of the Creative Commons Attribution license (http://creativecommons.org/licenses/by/4.0/). 